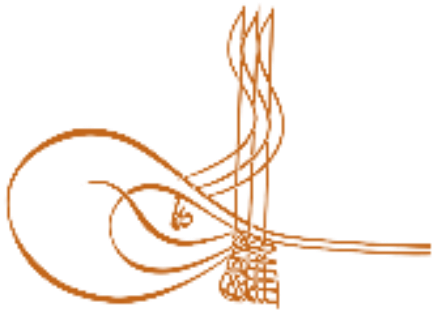

www.turkishstudies.net/social
Turkish Studies - Social Sciences

eISSN: $2667-5617$

Research Article / Araşttrma Makalesi

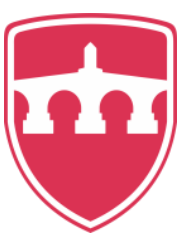

INTERNATIONAL

BALKAN

UNIVERSITY

Sponsored by IBU

\title{
Avrupa Birliği’nde Aşırı Sağa Etki Eden Faktörlerden Biri Olarak Ekonomik Kriz (2008- 2018)
}

Economic Crisis as one of the Factors Affecting the Far Right in the European Union (2008-2018)

\author{
Şükrü Cicioğlu* - Filiz Cicioğlu**
}

\begin{abstract}
An important consequence of the economic crisis that began in the USA in 2008 and the subsequent economic crisis experienced in many EU member states with the Greek crisis was the shift of political tendencies to the right parties in EU countries. In the recent years, far-right parties have achieved significant success in the elections in the EU's major powers such as France, Britain and Germany, as well as in Central European countries such as Austria and Poland. Although the economic crisis is an important factor in shifting to this far right, it is not enough solely. Because the extreme right in the countries such as Finland and Austria, which is thought to have not affected the crisis much, has increased, while the extreme right in Spain and Portugal has not increased compared to other countries even though it is heavily affected by the crisis. This has led to the necessity of introducing other factors in the rise of the extreme right. One of these factors is xenophobia, which reached its peak on the basis of the refugee crisis. However, xenophobia is based on the austerity policies that member states have to implement under pressure from EU institutions. In response to this situation, the public increases the votes of these radical parties which they have not tried before. This study will focus on the impact of the economic crisis on the rise of the extreme right, keeping other factors aside. In this context, the relationship between the economic crisis and the rise of the extreme right will be analyzed by examining the election results in the two countries affected by the crisis and the two countries which were most affected by the crisis and other less affected. It is planned to test the research questions by comparing the main economic data before and after the economic crisis, which is thought to be an important factor in the rise of the far right parties in the results of the local and general elections and presidential elections in these countries.
\end{abstract}

Structured Abstract: The European Union (EU) has entered the 1990s with the effort to add political unity to its economic unity by signing the Maastricht Treaty. It aimed to enter 2000s stronger with the goal of switching to the common currency. Nonetheless it found itself in a huge expansion wave with the cyclical environment caused by the end of the Cold War. In 2004, the Union experienced the biggest expansion of its

\footnotetext{
${ }^{*}$ Dr. Öğr. Üyesi, Sakarya Üniversitesi, Siyasal Bilgiler Fakültesi, İktisat Bölümü Asst. Prof. Dr.,, Sakarya University, Faculty of Political Sciences, Department of Economics ORCID 0000-0002-2629-3134

cicioglu@ sakarya.edu.tr

** Dr. Öğr. Üyesi, Sakarya Üniversitesi, Siyasal Bilgiler Fakültesi, Uluslararası İlişkiler Bölümü

Asst. Prof. Dr.,, Sakarya University, Faculty of Political Sciences, Department of International Relations

ORCID 0000-001-6535-0528

fsever@sakarya.edu.tr

Cite as/ Atıf: Cicioğlu, Ş., Cicioğlu, F. (2020). Avrupa Birliği’nde aşırı sağa etki eden faktörlerden biri olarak ekonomik kriz (2008-2018), Turkish Studies - Social, 15(2), 107-125. https://dx.doi.org/10.29228/TurkishStudies.40066

Received/Geliş: 08 December/Aralık 2019

Accepted/Kabul: 25 February/Şubat 2020

Checked by plagiarism software

Copyright $(C)$ INTAC LTD, Turkey 
history with the simultaneous participation of ten different countries and took important steps towards turning into a great power on a global scale. However, with the rejection of the Constitutional Treaty that it drafted at the beginning of this century in the referendums in France and the Netherlands which are the two founding members, the foundations of the future crisis has almost been laid. For the EU, which has not yet been able to overcome the effects of the constitutional crisis, the main problem will be the crisis it will experience in the economy, the area where it is stronger.

The crisis that emerged on the financial system in the USA has spread with the bankruptcy of important financial institutions one after another to other parts of the world and to the European geography in a short period of time. The crisis has turned into a deep economic shock within the EU, especially due to the fragile structures of countries such as Greece, Spain and Ireland. Emerging unemployment and government budget cuts in the fields of education and health caused social discomfort. In response to this situation, it caused reactions to immigrants and foreigners in Europe. The groups, who were unemployed due to the crisis and lost their assurance with the decrease of social spending, have turned towards far-right movements.

In this study, which tries to understand the relationship between the far-right and the economic crisis, the degree of exposure of the EU countries to the economic crisis were examined based on four criteria. These are date concerning unemployment, inflation, growth and budget deficit. Within the framework of these crisis indicators, two groups of countries are included as countries affected by the crisis and the countries relatively less. The level of progress of far-right trends in each country in the groups determined according to the relevant criteria is tried to be investigated. Thus, the impact of the degree of exposure to crisis on the progress of the far right in these countries is tried to be analyzed.

The foundation of correlating the rise of far-right parties with the economic crisis is based on the Nazi era. The idea that the economic conditions brought by the Great Depression of 1929 brought Hitler's Nazi Party to power created the expectation that each economic crisis would strengthen far-right trends. This situation has started to be discussed as far-right parties achieved significant electoral successes in some European countries after the 2008 economic crisis. Researches on whether the economic crises will directly lead to an increase in the vote of the far-right parties has reached different findings. The results of the research conducted by Funke et al. by examining over 800 elections taking place twenty countries in total between 1870-2014 determined that the far-right parties were the biggest beneficiaries of the financial crises. Another study supporting this research was done by Kriesi (2012). In this study, the first parliamentary elections held in thirty European countries after the collapse of Lehman Brother were examined and as a result it was determined that the countries benefiting from the crisis were populist parties (right and left) (Kriesi, 2012). Mudde, who is known for her work on the far-right, tried to reveal the effects of the crisis by comparing the pre-crisis (2004-2007) and post-crisis (2009-2013) vote rates of the far right parties in national elections in the EU member states. It is determined that between 2005 and 2013 support for far-right parties increased in nine of the eighteen European countries where there was a significant far-right party, while the other nine did not increase. Germany and France which are among these countries stand out as countries where the crisis has been relatively less troublesome, while Hungary and Latvia have been worse affected by the crisis. At the end of this study, Mudde falsified the claims that the economic crises increased the votes of the far-right parties (Mudde, 2014).

The findings attained in the study titled "European Populism in the Shadow of the Great Recession" (Vittori 2016) compiled by Hanspeter Kriesi and Takis Pappas are similar to Mudde's. Examining the relationship between the economic crisis and the rise of populism before and after the big recession, the authors found that populist parties has progressed in the countries with less affected by the economic crisis but there are also countries where such a populist tendency has not been experienced although it was affected by the crisis.

Another study with similar results has been done by Stockemer. Contrary to expectations, Stockemer found that the highest increases in the votes of the far-right parties took place in regions far from the impact of the crisis. The fact that far-right parties achieved high voting rates in countries where the crisis was less affected caused the questioning of the relationship between far-right support and the economic crisis. One of the findings of the study is that the economic crisis has a psychological effect rather than a real one.

As can be seen, there are different opinions in the literature in terms of studies examining the effect of economic crises on the rise of the far right. Because the economic crisis and its weakening effects provide a suitable ground for stimulating some potential trends and attitudes. The factors in times of crisis such as 
prescriptions imposed on the people, lack of preference, rejection of any alternative and exclusion of the people from the decision-making mechanism provide a suitable movement area for the use of far-right parties. The political crises accompanying the economic crises emerge as another important factor in the rise of the far right.

The contribution of this study to the above literature is that the subject is evaluated in terms of the countries with different levels of development by grouping the countries selected as samples in the study as countries that are relatively less affected and more affected by the crisis.

Countries are divided into two groups. Countries in the first group (Germany and Austria) have relatively less affected by the 2008 crisis. Firstly, how these countries were affected by the economic crisis in terms of various economic indicators (unemployment and growth) and the extent to which the political parties representing the extreme right in these countries have developed during the last decade have been examined. Then, the effect / ineffectiveness of the economic crisis on the rise of the far right in that country is tried to be analyzed. The countries in the second group (Greece and Italy) are the countries most heavily affected by the economic crisis. The same method was followed for these countries.

It is seen in the countries examined in this study that the economic crisis has not enhanced the farright in every country. In this case, factors other than the economic crisis (such as the number of migrants, the proportion of the minority population) should be taken into consideration regarding the rise of the far right.

Economic crises are a factor that "nourishes" even if they do not directly affect the increase of the far right's votes. This situation has likewise indirect effect in some countries. Even if their country has not been affected by the economic crisis, the citizens of developed countries who criticized the financial aid to the countries that entered the crisis have also showed their reactions to this aid by voting to the far-right parties in the elections.

In some countries although the impact of the economic crisis is very severe, far-right parties did not show an upward trend in the period under review. The social and political separation and the lack of national awareness in these countries can be showed as the reason for this situation (such as Spain and Belgium)

Italy and Greece, which are known to be the most affected ones by the economic crisis, are also among the countries that are most affected by the migrant crisis as they are on the route of transportation to Europe by sea. Especially these two countries was the first destination of many migrants who were trying to reach to the EU by sea and lost their lives to this end until March 18 agreement reached with Turkey. This is one of the biggest factors for the increase of far-right votes in these two countries. However, the crises experienced especially by Italy due to the rules of the Budget Agreement formed with the EU as one of the solutions of the economic crisis and the fact that the crisis has not been yet overcome in this country has still kept the popularity of the far right.

This study, for the very reason, was conducted to test the "economic crises nourish the extremes" hypothesis in the literature and it is seen that the economic crisis is the first factor that will come first when the causes of the rise of the far right are listed. However, the subsequent cyclical developments (such as the refugee crisis, the election of Trump as the US president, Brexit) also fed the extreme right. It is thought that as long as the long-term effects of these developments continue the political spectrum of many countries will be reshaped.

Keywords: Political economy, Far right, economic crisis, EU

Öz: ABD’de 2008 yılında patlak veren ve sonrasında hızla Avrupa'ya yayılarak pek çok AB üyesi ülkede hissedilen ekonomik kriz AB ülkelerinde yaşayan halkın siyasi tercihlerini sağ partilere kaydırmasıyla sonuçlanmıştır. Başta Fransa olmak üzere Almanya ve İngiltere gibi AB'nin büyük ülkeleriyle birlikte gerek Orta Avrupa ülkelerinde (Avusturya, Polonya) gerekse refah seviyesinin yüksek olduğu Kuzey Ülkeleri (Finlandiya, İsveç gibi)nde de son yıllarda aşırı sağ partiler seçimlerden oylarını arttırarak çıkmaya başlamışlardır. Ekonomik kriz aşırı sağın oylarını bu şekilde arttırmasındaki önemli faktörlerden biri olarak değerlendirilmektedir. Ancak krizin çok fazla etkilemediği düşünülen Finlandiya, Avusturya gibi ülkelerde aşırı sağın oylarını arttığı görülürken, İspanya ve Portekiz krizden yoğun bir şekilde etkilendiği halde bu ülkelerde aşırı sağ diğer ülkelere kıyasla yükselmemiştir. Bu durum aşırı sağın yükselişine etki eden başka faktörlerin de varlığının sorgulanmasına neden olmaktadır. Bu etkenlerin başında da 11 Eylül saldırılarından 
sonra $\mathrm{ABD}$ başta olmak üzere $\mathrm{AB}$ ülkelerinde de mülteci krizi ile birlikte daha da yoğunlaşan yabancı düşmanlığı gelmektedir. AB kurumlarının baskısıyla üye devletlerin uygulamak zorunda kaldıkları kemer sıkma politikaları da yabancı düşmanlığının yükseliş sebeplerinden biridir. Halkın bu duruma gösterdiği tepki daha önce denememiş oldukları bu radikal partilerin oylarında yükselişe sebep olmaktadır. Bu çalışma diğer etkenleri bir kenarda tutarak ekonomik krizin aşırı sağın yükselmesindeki etkisine odaklanacaktır. Bu çerçevede iki değişken arasındaki ilişki bir takım ekonomik göstergelerin ışığında sıralanan ülkeler arasından krizden etkilenen iki ülke ile görece krizden daha az etkilenen iki ülkedeki seçim sonuçları incelenerek analiz edilecektir. Bu ülkelerdeki seçim sonuçlarında aşırı sağ partilerin yükselmesinde önemli bir faktör olduğu düşünülen ekonomik krizin öncesi ve sonrasındaki başlıca ekonomik veriler karşılaştırılarak araştırma sorularının test edilmesi planlanmaktadır.

Anahtar Kelimeler: Politik ekonomi, Aşırı Sağ, Ekonomik Kriz, AB

\section{Giriş}

Avrupa Birliği (AB) 1990'lı yıllara Maastricht Antlaşması'nı imzalayıp, ekonomik birliğine siyasal birliği de ekleme çabası ile başlamıştır. Aynı zamanda ortak para birimine geçme hedefi ile birlikte 2000'li yıllara daha güçlü girmeyi hedeflemiştir. Ancak Soğuk Savaş'ın bitmesinin doğurduğu konjonktürel ortamla birlikte kendini büyük bir genişleme dalgasının içinde bulmuştur. 2004 yılında Birlik on ülkenin birden katılımıyla tarihinin en büyük genişlemesini yaşamış, küresel ölçekte büyük bir güce dönüşme yolunda önemli adımlar atmıştır. Ancak bu yüzyılın başında hazırladığı Anayasal antlaşmanın iki kurucu üye olan Fransa ve Hollanda'daki referandumlarda reddedilmesiyle birlikte adeta bundan sonra yaşayacağ 1 krizlerin de temelleri atılmıştır. Anayasa krizinin etkilerini henüz üzerinden atamayan AB için asıl önemli problem daha güçlü olduğu alan olan ekonomide yaşayacağı kriz olacaktır.

ABD'nin finans sektörünün bir alt dalında 2007 yılının yaz aylarında bir kriz çıktığında bu krizin küresel ekonomik sistem üzerinde bu kadar tahribata yol açacağı düşünülmemişti. İlk başlarda "likidite sıkışması" şeklinde tezahür eden kriz, kısa sürede ABD finans sisteminin tümüne yayılmıştır. ABD'nin dördüncü büyük yatırım bankası olan Lehman Brothers isimli şirketin 14 Eylül 2008'de iflas başvurusunda bulunması sorunun büyüklüğünün anlaşılmasını sağlamıştır. Başta bankalar olmak üzere finans kuruluşlarının arka arkaya iflaslarını ilan etmeleri kısa sürede gelişmiş ülkelerin ekonomilerini etkilemeye başlamıştır. Öyle ki krizin en fazla etkilediği ülke gruplarının başında gelen $\mathrm{AB}$ 'de de Avro bölgesi \% 4.1 küçülerek tarihinin en büyük daralmasını yaşamıştır (Öniş ve Kutlay, 2012).

2010 yılında bu yavaş büyümeye Yunanistan, İspanya, İrlanda gibi ülkelerin iflası da eklenince küresel finansal kriz önce AB'nin ekonomik krizine daha sonra da Avro bölgesinin iflas krizine dönüşmüştür. Böylelikle ekonomik alanda güçlü olan $\mathrm{AB}$, tarihinde ilk kez bu kadar derin bir ekonomik çatlakla karşı karşıya kalmıştır.

Krizin önemli sonuçlarının başında bütçe açığı ve işsizlik rakamlarındaki yükseliş gelmektedir. Bütçe açıklarının eğitim, sağlık, sosyal güvenlik gibi alanlardaki kesintilerle finanse edilmesi toplumsal rahatsızlıklara neden olmuştur (Ultan, 2016:74-75). Sosyal güvenlik koşullarının kötüleşmesinden en fazla sorumlu tutulan grup göçmenler olmuştur. Özellikle 2007 yılında gerçekleşen Bulgaristan, Romanya genişlemesi de halkta bu konuda rahatsızlığa sebebiyet vermiștir. İşsizlik sorununun da ortaya çıkmasında yine yabancıların payı olduğunu düşünen Avrupa halkları bu duruma tepki göstermektedirler. Oysa ki göçmenler Avrupalıların çalışmayı tercih etmediği işlerde çalışmak zorunda kalmaktadırlar. Bu durum da işsizliği göçmenler üzerinden okumanın çok doğru olmadığını göstermektedir.

Ekonomik krizden çıkmak için Troyka (Avrupa Merkez Bankası ve Avrupa Komisyonu ile Uluslararası Para Fonu)'nın krizle mücadele eden ülkelere dayattığı kemer sıkma politikalarının(sosyal harcamalarda kesintiler, artan işsizlik ve düşen ücretler) Avrupa 
vatandaşlarının $\mathrm{AB}$ kurumlarını sorgulamalarına neden olmuştur. Kriz sebebiyle işsiz kalan ve üye devletlerden gelen yardımların azalmasıyla bazı sosyal güvencelerini kaybeden kesimler, Suriye krizini takiben sayıları göçmenlerin ülkelerinin ekonomilerini zayıflattığı argümanını savunan aşırı sağ hareketlere yönelmişlerdir.

Aşırı sağ ile ekonomik kriz arasındaki ilişkiyi anlamaya çalışan bu çalışmada AB ülkelerinin ekonomik krizden etkilenme düzeyleri dört kriter ${ }^{1}$ esas alınarak incelenecektir. Bunlar, işsizlik, enflasyon, büyüme ve bütçe açığına ilişkin verilerdir. Bu kriz göstergeleri çerçevesinde krizden etkilenen ve görece daha az etkilenen ülkeler olarak iki grup ülkeye yer verilecektir. İlgili kriterlere göre belirlenen gruplardaki her bir ülkedeki aşırı sağ eğilimlerin gelişme düzeyi araştırılmaya çalışılmıştır. Böylelikle krizden etkilenme derecesinin ülkelerdeki aşırı sağın gelişimi üzerindeki etkisi araştırılmaya çalışılmıştır.

\section{2008 Küresel Ekonomik Krizi}

Sosyal bilimler açısından kriz, aniden ortaya çıkan ve kötü yönde gelişen büyük sıkıntı ve buhran anlamlarında kullanılmaktadır. Bu bağlamda ekonomik kriz, mal ve hizmet ile üretim faktörü ve döviz piyasalarındaki fiyat ve miktarlarda görülen belirli bir eşik üzerindeki şiddetli dalgalanmalar olarak ifade edilebilir (Kibritçioğlu, 2005: 504). Krizlerin genel olarak ortak özellikleri aniden ve beklenmedik bir şekilde ortaya çıkmalarıdır. Krizler kısa ve uzun süreli olabilir ve bulaşıcı bir etki göstererek çeşitli sektör ve ülkeler arasında yayılabilir (Aktan ve Şen, 2001: 1225-26). Bir ekonomide krizlerin makroekonomik göstergeleri olarak aşağıdaki hususlar dile getirilebilir (Başoğlu ve Ceylan, 2001: 550):

$\begin{array}{ll}\text { - } & \text { İşsizlik } \\ \text { - } & \text { Diş açıklar } \\ \text { - } & \text { Ekonominin büyüme hızı } \\ \text { - } & \text { Duş ticaret hadleri } \\ \text { - } & \text { Yerli paranı faiz oranları aşırı değerlenmesi } \\ \text { - } & \text { Enflasyon oranı } \\ \text { - } & \text { İç ve diş borçlar }\end{array}$

Bu göstergeler içerisinde toplumu hoşnutsuzluğa sevk eden, geleceğe dönük kaygıları arttıran ve politik tercihleri şekillendirebilen en önemlilerinin işsizlik, düşük büyüme ve enflasyon olduğu söylenebilir.

2008 Eylül Ayı'ndan önce ABD'de başlayan ve daha sonra dünyanın diğer bölgelerine yayılan küresel krizin temelinde büyük miktarda gayrimenkul talebi ve bunu finanse etmeye yönelik kredi hacmi yatmaktadır. ABD'de başlangıçta mortgage piyasasında fonların alıcıları geri ödeme potansiyeli yüksek, kaliteli bir sosyal sınıf idi(prime mortgage). ABD'de faizlerin düşük düzeyde seyretmesine bağlı olarak zaman içerisinde değişken faiz formatında bu krediler kredibilitesi daha düşük gruplara yönlendirilmiştir.(subprime mortgage). FED'in son dönemde faizleri peş peşe arttırması konut fiyatlarındaki düşüşle beraber gerçekleştiğinden dolayı bu tarz kredilerin geri ödenmesinde ciddi sıkıntılar oluşmaya başladı (Eğilmez,2009:66-67). Gelirlerinin üzerinde bir harcama eğilimi taşıyan ilgili kesimin bu davranışı enflasyonist süreci besledi. FED'in 2004 yılından itibaren faiz artışı politikası izlemesinin temel nedeni buydu. Faizler artınca borçlular kredi

\footnotetext{
${ }^{1}$ Her ne kadar bu dört kriter esas alınmış olsa da halkın ekonomik krizden daha fazla etkilenme düzeyiyle ilgili olduğu için işsizlik ve ekonomik büyüme rakamlarına daha fazla önem verilmiştir.
} 
taksitlerini ödemede zorlanmış ve konut balonu patlayınca krize neden olmuştu (Yılmaz, 2013a: 33$35)$.

$\mathrm{Bu}$ esnada İngiltere, Almanya, Fransa ve İsveç gibi ülkeler yüksek getirisinden dolay1 ABD'deki bankaların tahvillerinden satın almışlardı. Ancak ABD'deki mali kriz bu ülkelerin ellerinde bulundurdukları tahvillerin sadece kağıt olarak kalmasına neden oldu. İlaveten petrol fiyatlarındaki artış ve tüketici kredilerinin de geri dönüşünün yeterli düzeyde olmaması buralarda da mali krizin çıkmasına sebebiyet verdi. Bunun sonucunda uluslararası yatırımcılar Avrupa'daki finans piyasalarından (XETRA, DAX ve FTSH) paralarını dolara çevirip çıktılar. Bunun yanında petrol fiyatlarının ortaya çıkmasıyla birlikte artan enflasyon Avro'ya değer kazandırma adına Avrupa Merkez Bankası (AMB)'nın faizleri arttırmasına neden oldu. Ancak bu durum Avrupa'daki iç sanayiyi olumsuz etkiledi. AMB'nın faizleri tekrar düşürmesiyle de durum olumluya dönmedi. Gerek ABD ve gerekse AB'nin düşük faiz politikası uygulamaları ve bu bölgelerdeki tüketicilerin gelirlerinin azalması bütün dünyada bu bölgelere yapılan ihracatı olumsuz etkilemiş, dolayısıyla ülkelerin iç ekonomileri küçülmüş ve işsizlik oranları artmıştır (Dursunoğlu, 2009:97).

Eurostat verilerine göre Avro para biriminin geçerli olduğu bölgede işsizlik oranı, 2012 yılı Mart sonu itibarıyla Avro'ya geçildiğinden bu yana kaydedilen en yüksek oran olan yüzde 10,9 şeklinde gerçekleşmiştir. Uygulanan tasarruf tedbirleri ve mali disiplin emek piyasalarındaki sorunu derinleştirmiş işsiz sayısı da rekor düzeyde yükselmiştir(AB Bakanlı̆̆ı, 2012: 2). Küresel işsizlik sorunsalında gelişmiş ülkeler ve $\mathrm{AB}$ ülkeleri işsizlik artışının yaklaşık \%40'ını içermektedirler (Gençler, 2011: 3).

Bu dönemde, Avro bölgesi yüzde 4,1 küçülerek tarihinin en büyük daralmasını yaşamıştır. Avro bölgesi, gelişmiş ekonomiler arasında en çok küçülen ve krizden çıkışta en yavaş büyüme süreçlerine sahip bir ekonomik blok olarak yer almıştır. 2010 yılından bu yana da aynı zamanda, üye ülkelerin yaşadığı ciddi borç krizi ve PIIGS (Portekiz, İrlanda, İtalya, Yunanistan ve İspanya) ülkelerindeki ekonomik daralma ile de mücadele zorunluluğu ortaya çıkmıştır (Y1lmaz, 2013b:58$59)$.

Kriz ilk olarak Fransız bankası BNP Paribas'ın fonlardan para çekmeleri dondurmasıyla kendini göstermiş sonrasında İngiltere bankası Northern Rock'ın likidite sorunu yaşamasını takiben İsviçre bankası USB'nin zarar açıklaması Avrupa'da krizin hızla yayıldığını göstermişti. Avustralya bankası Basis Capital 275 milyar dolarlık fonu çökmüş onu Almanya ve diğer ülkelerdeki banka fonları izlemiştir. Bankaların art arda gelen iflasları piyasalarda keskin düşüşlere neden olmuş ve ABD başta olmak üzere diğer merkez bankaları krizin etkileri azaltmak amacıyla faiz oranlarında indirime gitmişlerdir (İltaş, 2019: 103).

$\mathrm{AB}$ üyesi ülkeler içerisinde finansal krize düşen ilk ülke 2009 yılının son çeyreğinde Yunanistan olmuştur. Daha sonra İspanya, İrlanda, Portekiz ve İtalya ekonomilerinde de krizler yaşanmıştır. Derecelendirme kuruluşlarının bu ülkelere verdikleri notları düşürmeleriyle bu ülkelerin riskleri artmış ve dış yardıma başvurmak zorunda kalmışlardır. Bu ülkelerdeki temel yapısal problemler arasında yüksek bütçe ve cari açıklar, Maastricht Kriterlerine önem verilmemesi, maliye politikasında gevşeklik ve rekabet dezavantajları sayılabilir (Erslan ve Timurtaş, 2015:30-31).

\section{Avrupa'da Aşırı Sağın Yükselişi}

Avrupa'da aşırı sağın yükselişi yeni bir durum değildir. Ancak son dönem gelişmeleri bu konunun Avrupa ülkelerinde yeniden gündeme gelmesine sebep olmuştur. Bu gelişmelerden bazıları:

- $\quad$ Avrupa'nın içinde bulunduğu ekonomik kriz, yavaş ekonomik büyüme ve göçmen krizinin sebep olduğu ekonomik sorunlar,

- $\quad$ Rusya'nın yükselişi

Turkish Studies - Social, 15(2) 
- $\quad$ Brexit

- $\quad$ Donald Trump'in ABD seçimlerindeki beklenmeyen zaferi

Aşırı sağın merkez partilere karşı kullandığı söylem Avrupa'da çok kültürlülük üzerinden işleyen hegamon söylemin reddedilmesidir. Merkez partiler (liberal, muhafazakar ya da sol..) geçmiş yıllarda göç, entegrasyon ve mülteci sorunlarıyla mücadele etmek için çok kültürlülük politikalarını savunmuşlardır. AB kurumları da çok kültürlülügü̈, etno-çoğulculuk, etno-milliyetçilik ve yabancı düşmanlığına karşı öncelemişlerdir. İktidardaki partiler, AB kurumları ve liberal medya şirketleri tarafından desteklenen Avrupa politik ortamı, aşırı sağın milliyetçi ve dışlayıcı söylemini marjinal hale getirmiştir. Aşırı sağın Müslümanlar, mülteciler ve entegrasyonla ilgili kullandığı dil AB için bir tehdit olarak gösterilmiştir. Ancak son yapısal gelişmeler ve seçim sonuçları aşırı sağı marjinal olmaktan çıkarıp hegamonya karşıtı hale getirmiştir. Bu durum Avrupa siyasetinde II. Dünya Savaşı'ndan beri varolmayan aşırı sağ partilerin yeniden sistemde yerini almasına sebep olmuştur. «Eski düzenin sonu» olarak adlandırılan Avrupa yeni politik düzeninde merkez partiler iktidarlarını korumaya devam etmektedirler ancak aşırı sağ partiler tarafindan ciddi bir meydan okuma ile karş1 karşıya olduklarını söylemek yanlış olmayacaktır(Balcı ve Cicioğlu, 2019).

Aşııı sağ partiler yakın zamanda "sıfir toplam” tasarısını², son nokta diye adlandırılabilecek yeni bir söylemle daha yalın olarak anlatmaya başlamışlardır. Bu söylem, sorun giderilmezse gelecekte oluşabilecek en kötü ihtimalin gerçekleşmesini önlemek için şimdiden atılacak en keskin adımları meşrulaştırma peşindedir. Bardağ hali yaratmaya çalışan aşırı sağ söylem, acilen önlem alınmazsa bu olumsuz durumdan geri dönülemeyeceği korkusu üzerinden siyaset yapmaktadır (Kallis, 2015: 15-16).

Ekonomik krizler mevcut yönetimlere karşı halkın güvenini sarstığı için siyasi krizleri de beraberinde getirmektedir. Bu durum İrlanda ve Portekiz'de hükümetlerin krizlere karşı tedbir alamayarak erken seçime gitmelerini gerekli kılmıştır. Aşırılıktan etkilenen seçmenler siyasetin değişmesine ilişkin taleplerini sandığa yansıtmaktadırlar. Ulusal kimlikleri vurgulayan aşırı sağcı söylemler ile ekonomik kriz ortamlarının paralel gittiği düşünüldüğünde $A B$ 'nin içinde bulunduğu kriz daha iyi anlaşılmaktadır. Borç yükü, düşük ekonomik büyüme, ve işsizlik gibi sorunlarla karş1 karşıya kalan $\mathrm{AB}$ halkları bu sorunlara çözüm üretilmemesi sonucunda aşırı sağcı eğilimleri olan partilere yönelmektedirler (İnanç ve Çetin, 2011:22-24).

\section{Ekonomik Kriz-Așırı Sağ İlişsisine Dair Literatür Taraması}

Aşırı sağ partilerin yükselişi ile ekonomik kriz arasında bir ilişki kurulmasının temeli Nazi dönemine dayanmaktadır. 1929 Büyük Buhranı'nın ortaya çıkardığı ekonomik koşulların Hitler'in Nazi Partisi'ni iktidara getirdiği fikri, her ekonomik krizin aşırı sağ eğilimleri güçlendireceği beklentisini oluşturmuştur. Bu durum 2008 ekonomik krizinin ardından da bazı Avrupa ülkelerinde aşırı sağ partilerin önemli seçim başarıları elde etmesiyle yeniden tartışılır hale gelmiştir.

Ekonomik krizlerin doğrudan aşırı sağ partilerin oy artışına sebep olup olmayacağına dair araştırmalar farklı bulgulara ulaşmıştır. Bu araştırmalardan Funke ve diğerleri tarafından 1870-2014 yılları arasındaki toplam yirmi ülkede gerçekleşen ve 800'ün üzerinde seçimi inceleyerek yapılan araştırmanın sonuçları aşırı sağ partilerin finansal krizlerin en büyük yararlanıcıları olduğunu saptamıştır. Bu araştırmada aşırı sağ partilerin ortalama olarak, sistemik finansal krizleri takip eden beş yıl içinde kriz öncesine göre oylarında yaklaşık \% 30’luk bir artışın meydana geldiği tespit

\footnotetext{
2 Aristotle Kallis sıfır toplam tasarısını şöyle açıklamaktadır: Aşırı sağ partiler genellikle kendi dışlayıcı "kimlik siyasetlerini" çarpıcı bir "sıfır toplamlı" vizyonla desteklemektedir. Bunun temel varsayımlarından biri şudur: Ekonomik ve sosyal kaynaklar sınırlıdır ve bu yüzden herhangi bir ülkede göçmen sayısının artması o ülkedeki kaynakları çok ciddi bir şekilde baskı altına almaktadır ve de toplumun çoğunluğunu zorlayacak bir rekabete yol açmaktadır. Bu vizyon ise bir grubun kazancının öteki grubun (eşit şekilde ya da çoğunlukla aşırı derecede daha yüksek) kaybı olduğunu öngörmektedir. (Kallis, 2015: 15)
} 
edilmiştir (Funke vd.,2016). Bu araştırmayı destekleyen bir başka çalışma Kriesi (2012) tarafindan yapılmıştır. Bu çalışmada Lehman Brother'ın çöküşünden sonra otuz Avrupa ülkesinde yapılan ilk parlamento seçimlerine bakılmış ve sonuçta krizden faydalanan ülkelerin popülist partiler (sağ ve sol) olduğu tespiti yapılmıştır (Kriesi,2012).

Yukarıdaki çalışmalarda ekonomik krizin aşırı sağın yükselişinde çok önemli bir etken olduğu vurgulanmıştı. Așırı sağ ile ilgili çalışmaları ile bilinen Mudde, 2014 yılında yaptı̆̆ çalışmada AB üyesi ülkelerde kriz öncesi (2004-2007) ve kriz sonrası (2009-2013) aşırı sağ partilerin ulusal seçimlerde aldıkları oy oranlarını kıyaslayarak krizin etkilerini ortaya çıkarmaya çalışmıştır. Mudde bu çalışmada yirmi sekiz AB üyesi ülkeden on tanesinde- ki bunların dördü ekonomik krizden yoğun bir şekilde etkilenip kurtarma paketleri alan Güney Kıbrıs, İrlanda, Portekiz ve İspanya gibi ülkeler-aşırı sağ partilerin yükselişinin görülmediği tespitini yapmıştır. Kurtarma paketi alan ülkelerden Yunanistan'da Altın Şafak Partisi'nin ciddi bir oy artışı söz konusu olmuştur. 2005-2013 yılları arasında önemli bir aşırı sağ partinin olduğu on sekiz Avrupa ülkesinin dokuzunda aşırı sağ partilere destek artmışken, diğer dokuzunda artış olmadığı tespit edilmiştir. Bu ülkelerden Almanya ve Fransa krizin görece daha az sıkıntılı geçtiği ülkeler olarak göze çarparken, Macaristan ve Letonya krizden daha kötü etkilenmiştir. Mudde bu çalışmanın sonunda ekonomik krizlerin aşırı sağ partilerin oylarını arttırdığı yönündeki iddiaları yanlışlamıştır (Mudde, 2014).

Hanspeter Kriesi ve Takis Pappas tarafindan derlenen "European Populism in the Shadow of the Great Recession" (Vittori 2016) isimli çalışmada ulaşılan sonuçlar da Mudde ile benzerlik göstermektedir. Büyük resesyon öncesi ve sonrasında ekonomik kriz ve popülizmin artışı arasındaki ilişkiyi inceleyen yazarlar ekonomik krizden daha az etkilenen ülkelerde popülist partilerin büyüdüğü ancak krizden etkilendiği halde böyle bir popülist eğilimin yaşanmadığı ülkelerin olduğu tespitini yapmışlardır. Örneğin, büyüme hızı konusunda çok zarar görmeyen İsveç’te popülizm yükselmiştir, buna karşın ekonomik krizden önemli oranda etkilenen İrlanda'da ise hiçbir popülist parti ortaya çıkmamıştır. Araştırmada ortaya konulan bir diğer bulgu da ekonomik krizler kadar hatta bazen onlardan daha fazla olarak siyasi krizlerin de popülizmi etkilediği şeklindedir. Güney ve Doğu Avrupa ülkelerinde ve Finlandiya'da popülizmin yüksek oluşunun sebebi olarak siyasi krizler görülmüştür. Her iki krizin de -siyasi ve ekonomik- birlikte yaşandığ 1 ülkelerde ise-Yunanistan, Macaristan, İtalya gibi- popülizmin daha da yüksek olduğu varılan tespitler arasındadır (Uzunçayır, 2017: 375-76).

Benzer sonuçlara ulaşan bir başka araştırma da Stockemer tarafindan yapılmıştır. Stockemer, beklenenin aksine aşırı sağ partilerin oylarında en yüksek artışların krizin etkisinden daha uzak bölgelerde yaşandığını tespit etmiştir. Krizin daha az etkilediği ülkelerde aşırı sağ partilerin yüksek oy oranları elde etmiş olması aşırı sağa destek ve ekonomik kriz arasındaki ilişkinin sorgulanmasına neden olmuştur. Çalışmanın bulgularından biri de ekonomik krizin gerçek etkiden çok psikolojik bir etki yaptığ 1 doğrultusundadır. AB ülkelerinde yaşayan halkların eğer bir tedbir almazlarsa kendilerinin de Yunanistan, İspanya ve Portekiz gibi ülkelerdeki ekonomik koşullarla karşılaşacakları düşüncesinin hakim olduğu çalışmada belirtilmiştir (Stockemer,2017:1547).

Görüldüğü üzere ekonomik krizlerin aşırı sağın yükselişine olan etkisinin incelendiği çalışmalar bakımından literatürde farklı görüşler mevcuttur. Zira ekonomik kriz ve onun zayıflatıcı etkileri bazı potansiyel eğilim ve tutumların harekete geçirilmesi için uygun bir zemin hazırlamaktadır. Kriz dönemlerinde halka dayatılan reçeteler, tercih eksikliği, herhangi bir alternatifin reddi ve halkın karar mekanizmasından dışlanması gibi etmenlerin öne çıkışı, aşırı sağ partilerin kullanımı için uygun bir hareket alanı sağlamaktadır. Ekonomik krizlere eşlik eden siyasal krizler de aşırı sağın yükselişindeki diğer bir önemli etmen olarak karımıza çıkmaktadır.

\section{4. $\quad$ Ülke Örnekleri İle Ekonomik Kriz-Aşırı Sağ İlişkisi}

Bu bölümde incelenecek olan ülkeler iki gruba ayrılmıştır. Birinci gruptaki ülkeler (Almanya ve Avusturya) 2008 krizinden görece daha az etkilenmişlerdir. Bu ülkelerin önce çeşitli ekonomik 
göstergeler (işsizlik ve büyüme) bakımından ekonomik krizden nasıl etkilendikleri ve bu ülkelerdeki aşırı sağı temsil eden siyasi partilerin son on yıllık periyotta nasıl bir gelişim gösterdiklerine bakılmıştır. Ardından o ülkede ekonomik krizin aşırı sağın yükselişindeki etkisi/etkisizliği analiz edilmeye çalışılmıştır. İkinci gruptaki ülkeler(Yunanistan ve İtalya) ise ekonomik krizden en yoğun etkilenen ülkelerdir. Bu ülkeler için de aynı yöntem izlenmiştir.

\subsection{Almanya}

\section{Ekonomik Kriz}

Almanya ekonomik krizden en az etkilenen ülkelerin başında gelmektedir. 2009-2013 döneminde Alman ekonomisinde büyüme hızında bir yavaşlama olduğu görülmüş, ancak bu durum işsizlik oranlarına yansımamıştır. 2013'ten sonra ise işsizlik oranlarında düşüşler kaydedilmiş ve büyüme hızında küçük bir artış gözlenmiştir. Almanya küresel krizi diğer $A B$ ülkeleri ile karşılaştırıldığında daha hafif atlatmıştır. Bunun nedeni olarak üç unsur öne çıkmaktadır:2003 senesinde Gerhard Schröder tarafından hayata geçirilen ve iş piyasasına yönelik değişiklikler içeren Hartz reformları, avronun Alman markına kıyasla daha zayıf bir para birimi olması nedeniyle rekabet gücünün artması ve Alman sanayisinin esnekliği (Çetin,2017: 18).

Gerek nüfusu gerekse ekonomik yapısı ile $\mathrm{AB}$ içindeki en önemli ülke konumunda olan Almanya Birlik'in finansmanına en büyük katkıyı sağlamaktadır. Avrupa Merkez Bankası'nın sermayesinin en büyük payının da Almanya tarafından sağlanması ve özellikle Avrupa Finansal İstikrar Mekanizmas1 (European Financial Stability Mechanism-EFSM), Avrupa İstikrar Mekanizmas1 (European Stability Mechanism-ESM) ve Avrupa Finansal İstikrar Fonu (European Financial Stability Facility-EFSF) gibi fonların büyük ölçüde Almanya tarafından finanse edilmesi Almanya'nın Birlik üzerindeki etkisini kriz sonrası arttırmıştır. Bu çerçevede Yunanistan'ın yanında İspanya, Portekiz ve İrlanda gibi krizden etkilenen diğer ülkelere de verilen finansal destek bu kurumlar tarafindan çıkartılan tahviller yoluyla sağlanmış ve bu tahvillere Almanya yüzde otuz oranında garantör olmuş ve riskin önemli bölümünü üstlenmiştir. Bu şartlar altında büyük oranda ödemeye katk1 sağlayan ve verilen garantilerin en büyük kısmını üstlenen Almanya yapılan ödemelerin sonrasında koyulan koşulların tayini konusunda da çok etkin bir rol oynamıştır (a.g.e., 20). Almanya Avrupa Birliği içinde gittikçe etkinleşen liderliği ile Birlik içinde kopmaları önlemeye ve farklılıkları gidermeye çalışırken özellikle baş gösteren mülteci krizinin sonucunda kamuoyunun tepkisi ile de mücadele etmek zorunda kalmıştır.

Tablo 1: Küresel Kriz Sonrası Almanya'da Makro Ekonomik Göstergeler

\begin{tabular}{|l|l|l|l|l|l|l|l|l|l|l|}
\hline & $\mathbf{2 0 0 8}$ & $\mathbf{2 0 0 9}$ & $\mathbf{2 0 1 0}$ & $\mathbf{2 0 1 1}$ & $\mathbf{2 0 1 2}$ & $\mathbf{2 0 1 3}$ & $\mathbf{2 0 1 4}$ & $\mathbf{2 0 1 5}$ & $\mathbf{2 0 1 6}$ & $\mathbf{2 0 1 7}$ \\
\hline Büyüme Hızı & 0,8 & $-5,6$ & 3,9 & 3,7 & 0,7 & 0,6 & 1,9 & 1,5 & 1,9 & 2 \\
\hline $\begin{array}{l}\text { Enflasyon } \\
\text { (Tüfe) }\end{array}$ & 2,8 & 0,2 & 1,1 & 2,5 & 2,1 & 1,6 & 0,8 & 0,1 & 0,4 & 1,6 \\
\hline İşsizlik & 2,8 & 0,2 & 1,1 & 2,5 & 2,1 & 1,6 & 0,8 & 0,1 & 0,4 & 1,6 \\
\hline $\begin{array}{l}\text { Bütçe } \\
\text { Açığı/GSYH }\end{array}$ & $-0,18$ & $-3,23$ & $-4,22$ & $-0,96$ & $-0,03$ & $-0,14$ & 0,33 & 0,64 & 0,82 & 1,6 \\
\hline
\end{tabular}

Kaynak: OECD (2018), General government deficit (indicator). doi: 10.1787/77079edb-en ve http://www.imf.org/en/countries 05 Nisan 2018. 


\section{Aşırı Să}

Almanya'da aşırı sağın gelişimi diğer Batı Avrupa ülkeleriyle karşılaştırıldığında farklılık göstermektedir. Geçmişte yaşanan Nazi tecrübesi ve faşizm geçmişi bugünkü Alman siyasal ve sosyal yaşamının düzenlenmesinde etkili olmuştur. Geçmişte yaşanan acı tecrübelerin tekrar edilmemesi ve siyasal istikrarın korunması adına getirilen bir takım düzenlemeler ve alınan önlemlerle, ülkede aşırı sağ partinin kuruluşu ve sonrasındaki faaliyetleri sıkı bir denetime tabi tutulmuştur. Bu nedenle ortaya çıkmış olan aşırı sağ partiler ya uzun ömürlü olamamış ya da faşist ideolojiye yakın söylemler üretmesi nedeniyle izlemeye alınarak kapatılma tehlikesiyle karşı karşıya kalmıştır. Bu durumun, Almanya'daki aşırı sağ partilerin diğer Batı Avrupa ülkelerindeki gibi yükseliş gösterememesinin nedenlerinden biri olduğu söylenebilir. Bir diğer neden olarak toplumun bu partilere karşı mesafeli duruşu gösterilebilir. Özellikle geçmişteki olayları tecrübe eden toplumun belli kesimleri aynı şeylerin yaşanmaması adına kurulmuş olan aşırı sağ partilere karşı mesafeli olmuştur. Toplumda bu partilerin söylemlerini kısmen destekleyenler olsa da seçimlerde bu partilere oy verme konusunda çekimser bir tutum almışlardır (Tandoğan, 2019).

İki Almanya'nın birleşmesi konusu aşırı sağ partiler tarafından bir propaganda malzemesi olarak kullanılmıştır. Bölünmüş olan Alman toplumunu bir çatı altında toplayabilecek güç olarak kendilerini gösteren aşırı sağ partilerin bu söylemleri, 1990 yılında Doğu ve Batı Almanya'nın birleşmesiyle sona ermiştir. İki Almanya'nın birleşmesi sonrasında yaşanan ekonomik dalgalanmalara rağmen, devletin hala topluma yüksek refah seviyesi imkânı sunması, aşırı sağ partilerin ekonomi üzerinden yaptığı propagandaları zayıflatmış ve bu durum toplumun büyük kesiminin aşırı sağ partilere yönelişini engellemiştir(Backes ve Mudde, 2000: 466-67).

Alman Ulusal Demokratik Partisi/Nationaldemokratische Partei Deutschlands (NPD), 1964 yılında kurulmuştur. Parti, radikal milliyetçi ve popülist bir politik duruşa sahip olup siyasi yelpazenin en sağında yer almaktadır. NPD, güçlü bir ekonomisi olan Almanya'nın Avrupa Birliği'ne olan gereksiz ekonomik bağımlılığından vazgeçerek, Avro'dan çıkılarak yeniden eski para birimi olan Alman markının kullanılması görüşlerini savunmaktadır.

Almanya için Alternatif (Almanca: Alternative für Deutschland, AfD), Almanya'da 2013 yılında kurulan henüz çok genç bir partidir. Aşırı sağ görüşe sahip ve $\mathrm{AB}$ şüphecisi bir siyasi partidir. 2013 seçimlerinde baraj \%5.0 iken \%4.7 oy alarak meclise girmeyi kıl payı kaçırmıştır. Partinin kurulduğu sıralar Avrupa'da Euro krizi yaşanmakta ve AB içerisinde Yunanistan'a yardım konusu tartışılmaktaydı. Diğer taraftan Arap Baharı ile başlayan göçmen krizi de gündemi meşgul eden diğer bir sorundu. AfD bu sorunları başarıyla okudu ve kendi politikasını bu yönden geliştirdi(İltaş, 2019: 121). 2014 Avrupa Parlamentosu seçimlerinde parti Almanya'daki 96 koltuktan 7'sini almay1 başarmıştır. Tablo 2'de görüleceği üzere 2017 Almanya federal meclisi seçimlerinde 94 sandalye ve $\% 12.6$ oy alarak ilk defa federal meclise girmeyi başarmıştır. (www.electionresources.org, 2019).

Tablo 2: Alman Federal Meclisinde Aşırı Sağ Partilerinin Seçim Sonuçları (2008-2018)

\begin{tabular}{|l|l|l|l|l|}
\hline Seçim & \multicolumn{3}{|c|}{ Oy Oranı } & \multicolumn{2}{l|}{ Sandalye Sayısı } \\
\hline & NPD & AFD & NPD & AFD \\
\hline $\mathbf{2 0 0 9}$ & $\% 1.8$ & - & $0 / 620$ & - \\
\hline $\mathbf{2 0 1 3}$ & $\% 1.5$ & $\% 4.7$ & $0 / 631$ & $0 / 631$ \\
\hline $\mathbf{2 0 1 7}$ & $\% 0.1$ & $\% 12.6$ & $0 / 709$ & $94 / 709$ \\
\hline
\end{tabular}

Kaynak: http://www.electionresources.org/de/ 


\section{Ekonomik Kriz-Aşırı Sağ İlişkisi}

Almanya'da büyüme hızının düşmeye başladığı dönemde AFD'nin yeni kurulmasının etkisiyle aşırı sağın oy oranında bir artış olmuştur. Ekonomik krizden etkilenmeyen bir ülke olarak aşırı sağın artış nedeninin Alman ekonomisi tarafindan Yunanistan'a verilen yardımlara halkın gösterdiği tepki olduğu düşünülmektedir. Ancak asıl artışın görüldüğü 2017 seçimlerinin ekonomik krizin izlerinin silindiği bir döneme denk gelmiş olması, aşırı sağın oylarının artmasında başkaca etkenlere (göçmen krizi vs.) bakılmasını gerekli kılmaktadır.

\subsection{Avusturya}

\section{Ekonomik Kriz}

Avusturya 2009 yılında yaşadığı negatif büyüme dışında krizin etkilerinin ağırlıklı olarak hissedildiği 2013 'e kadar olan periyotta ortalama \% 1.5 pozitif bir büyüme elde etmiştir. İşsizlik rakamlarında ise bariz bir değişim yoktur. (\% 5 civarında..) 2013'ten sonra ise büyüme hızını az da olsa arttırmış, fakat işsizlik oranlarında önemli bir değişim oluşmamıştır.

Avusturya ekonomisini güçlü tutan faktörlerden biri bu ülkenin Latin Amerika ve Asya'nın yükselen ekonomilerinden kaynaklanan güçlü talepten dolaylı olarak, Alman ekonomisinde yaşanan gelişmelerden ise doğrudan faydalanıyor olmasıdır. Tablolara bakıldığında Almanya'nın büyüme trendi ile etkileşim halinde olduğunu görmek mümkündür. Diğer yandan hizmetler sektöründe artan işgücü talebi işsizlik oranlarında ciddi değişimlere yol açmamıştır (AB Genel Sekreterliği, 2011: 74$75)$.

Tablo 3: Küresel Kriz Sonrası Avusturya'da Makro Ekonomik Göstergeler

\begin{tabular}{|l|l|l|l|l|l|l|l|l|l|l|}
\hline & $\mathbf{2 0 0 8}$ & $\mathbf{2 0 0 9}$ & $\mathbf{2 0 1 0}$ & $\mathbf{2 0 1 1}$ & $\mathbf{2 0 1 2}$ & $\mathbf{2 0 1 3}$ & $\mathbf{2 0 1 4}$ & $\mathbf{2 0 1 5}$ & $\mathbf{2 0 1 6}$ & $\mathbf{2 0 1 7}$ \\
\hline Büyüme Hızı & 1,5 & $-3,8$ & 1,9 & 2,8 & 0,7 & 0,1 & 0,6 & 1 & 1,5 & $\mathbf{2 , 3}$ \\
\hline $\begin{array}{l}\text { Enflasyon } \\
\text { (Tüfe) }\end{array}$ & 3,2 & 0,4 & 1,7 & 3,5 & 2,6 & 2,1 & 1,5 & 0,8 & 1 & $\mathbf{1 , 6}$ \\
\hline İșsizlik & 4,1 & 5,3 & 4,8 & 4,6 & 4,9 & 5,3 & 5,6 & 5,7 & 6 & $\mathbf{5 , 7}$ \\
\hline $\begin{array}{l}\text { Bütçe } \\
\text { Açığı/GSYH }\end{array}$ & $-1,5$ & $-5,33$ & $-4,44$ & $-2,55$ & $-2,19$ & $-1,95$ & $-2,69$ & $-1,33$ & $-1,64$ & \\
\hline
\end{tabular}

Kaynak: OECD (2018), General government deficit (indicator). doi: 10.1787/77079edb-en ve http://www.imf.org/en/countries 05 Nisan 2018.

\section{Aşırı Să}

Nazizm'in en önemli ismi Hitler'in ülkesi olan Avusturya'da tekrar güçlenen aşırı sağ partiler ve bu durumun doğurduğu yabancı karşıtı popülist söylemler, hem Almanya'nın hem Yahudilerin hem de dünyanın uzun yıllar kabus olan bu düşüncenin yeniden filizlendiğini akıllara getirmektedir.

Avusturya'da aşırı sağın temsilcisi olarak görülen Avusturya Özgürlük Partisi (Freiheitliche Partei Österreichs, FPÖ), 1956'da Avusturya'nın siyasetinin "Üçüncü Kampı" nı temsil eden, yani hem sosyalizme hem de Katolik din adamcılığına karşı olan pan-Almancı ve ulusal liberalleri temsil eden kısa ömürlü Bağımsızlar Federasyonu'nun (VdU) halefi olarak kurulmuştur. Heinz-Christian Strache liderliğindeki parti, Avrupa Parlamentosu'ndaki Milletler ve Özgürlükler grubunun yanı sıra Milletler ve Özgürlükler Avrupası'nın bir üyesidir. 1999 yasama seçiminde, FPÖ \% 26.9 oy alarak ikinci sırada yer aldı ve bu ülke çapında aldığı en iyi sonuç oldu. Heinz-Hıristiyan Strache'nin 
önderliğinde, FPÖ kendisini bir Heimat ${ }^{3}$ ve sosyal parti olarak tanımlamaya odaklanmıştır. Bu, partinin Avusturyalı kimlik ve sosyal refahın garantörü olarak rolünü desteklediği anlamına gelir. Ekonomik olarak, refah devleti desteğiyle birlikte özelleştirme ve düşük vergilerle düzenlenmiş liberalizmi destekler; Ancak mevcut göç politikalarına devam edilirse refah devletini desteklemenin imkansız olduğunu savunmaktadır. 2017 yasama seçimlerinde FPÖ \%26 oy alarak 183 sandalyeli mecliste 51 sandalye elde etmiştir. Bu sonuçla birinci parti olan Sebastian Kurz'un liderliğindeki Halk Partisi (ÖVP) ile koalisyon kurmuştur (http://www.electionresources.org, 2019).

Tablo 4:Avusturya Ulusal Meclisinde Aşırı Sağ Parti FPÖ’nün Seçim Sonuçları (20082018)

\begin{tabular}{|l|l|l|}
\hline Seçim & $\begin{array}{l}\text { Oy } \\
\text { Oranı }\end{array}$ & $\begin{array}{l}\text { Sandalye } \\
\text { Sayısı }\end{array}$ \\
\hline $\mathbf{2 0 0 8}$ & $\% 17.5$ & $34 / 183$ \\
\hline $\mathbf{2 0 1 3}$ & $\% 20.5$ & $40 / 183$ \\
\hline $\mathbf{2 0 1 7}$ & $\% 26$ & $51 / 183$ \\
\hline
\end{tabular}

Kaynak: http://www.electionresources.org/at/

\section{Ekonomik Kriz-Aşırı Să̆ İlişkisi}

Krizin en yoğun hissedildiği 2008-2013 arası dönemde Avusturya, ekonomik krizden etkilenmemesine rağmen aşırı sağ oylarında artış gözlenen bir ülkedir. 2013'ten sonraki dönemde ise aşırı sağ oylarda \% 5.5'luk bir artış görülmektedir. Bu durum Avusturya'nın da, ekonomik kriz olmayan ancak aşırı sağın yükseldiği ülkeler grubuna girdiğini göstermektedir.

Krizden az etkilenen ülkeler grubuna giren Avusturya'da aşırı sağcı FPÖ'nün oylarını artırmış olmasının en önemli sebebi olarak tıpkı Almanya'da olduğu gibi Avusturya hükümetinin krizden zarar gören üye ülkelere yönelik hazırlanan kurtarma paketlerine finansal destek sağlamak zorunda olması olarak kabul edilmektedir. Avusturyalı seçmen hükümetin finansal destek politikalarına tepkisini sandıkta göstererek FPÖ’nün oylarını arttırmıştır. Avusturya kamuoyunun bu tavrı AB içinde Avrupalılık bilincine dayalı "Birlik Ruhu"nun henüz arzu edilen düzeye ulaşmadığının, Avrupa hakları için ulusal kimliklerin hala ön planda olduğunun ve bu konuda aşılması gereken önemli aşamalar bulunduğunun bir göstergesidir (Güler, 2014).

\subsection{Yunanistan}

\section{Ekonomik Kriz.}

Aşağıdaki tabloya göre Yunanistan'ın işsizlik ve büyüme rakamlarına bakıldığında bu krizi derinlemesine yaşayan en önemli ülkenin Yunanistan olduğu görülmektedir. 2008 y1lında \%7.8 olan işsizlik oranı 2013 yılında \%27.5 seviyesine kadar çıkmış 2017 de ise \%23 seviyesindedir. 2011 yılında PIIGS ülkeleri arasında en yüksek işsizlik oranı yüzde 20 olarak İspanya'da gerçekleştiğinde, Yunanistan'da söz konusu oran yüzde $15^{\prime}$ ler seviyesindeydi. İspanya'ya bu anlamda Yunanistan 2012 yılının ilk çeyreğinde yetişmiş ve işsizlik yüzde 24 olmuştur (Yılmaz, 2013b:72). Büyüme rakamları da 2013'e kadar negatif yönlü gelişmiştir. Daha sonraki periyotta ise ortalama \%1 civarında olmuştur. Özellikle iç talepteki daralma yanında ihracat performansının olumsuz olması iktisadi faaliyetleri azaltmıştır. İç talebin azalması ise mali disiplin, ücret kesintileri ve krediye ulaşımdaki zorluktur (AB Bakanlığı, 2012). İktisadi faaliyetlerdeki azalma ve mali disiplinin enflasyon oranlarını da aşağıya doğru baskıladığı gözlemlenmektedir.

\footnotetext{
${ }^{3}$ Heimat, vatan anlamına gelen "homeland" ve kültürel kimlik anlamına gelen "cultural identity” kelimelerinin birleşimi için kullanılmaktadır
} 
Yunanistan ekonomik krizi, temelde kamuda gelir gider dengesini sağlama amacından uzaklaşmasına bağlı şekillenmiştir. Hükümetler mali disiplini sağlamaya dönük olarak ciddi çabalar sarfetmemişlerdir. Bu durumun ortaya çıkardığı açığı Avrupa Birliği’nden temin edilen düşük maliyetli fonlarla karşılamaya çalışmışlardır. Bu durumun müsebbibi ise kamu emekçilerinin gerçeklikten uzak ücretleri ve sosyal harcamaları olmuştur. İlave olarak yüksek askeri harcamalar, yolsuzluk ve kayıt dışılık mali disiplini bozan diğer konulardır (Dağdelen, 2011: 4). Dış kaynaklı nedenler ise; yabancı yatırımların düşüklüğü, ve Avrupa Birliği'nin kural ve kıstaslarına adapte olmaya yönelik baskılarıdır. Bunun yanında Yunanistan'ın, Avro bölgesi üyesi olabilmek için sağlanması gereken makroekonomik göstergeleri (1997-2003 aras1) sağlama durumunu Avrupa Birliği'ne bildirme konusunda aldatıcı olduğu söylenebilir (Durusoy ve Şamiloğlu, 2012:90-91).

Tablo 5: Küresel Kriz Sonrası Yunanistan'da Makro Ekonomik Göstergeler

\begin{tabular}{|l|l|l|l|l|l|l|l|l|l|l|}
\hline & $\mathbf{2 0 0 8}$ & $\mathbf{2 0 0 9}$ & $\mathbf{2 0 1 0}$ & $\mathbf{2 0 1 1}$ & $\mathbf{2 0 1 2}$ & $\mathbf{2 0 1 3}$ & $\mathbf{2 0 1 4}$ & $\mathbf{2 0 1 5}$ & $\mathbf{2 0 1 6}$ & $\mathbf{2 0 1 7}$ \\
\hline Büyüme Hızı & $-0,3$ & $-4,3$ & $-5,5$ & $-9,11$ & $-7,3$ & $-3,2$ & 0,4 & $-0,2$ & 0 & $\mathbf{1 , 8}$ \\
\hline $\begin{array}{l}\text { Enflasyon } \\
\text { (Tüfe) }\end{array}$ & 4,2 & 1,3 & 4,7 & 3,1 & 1 & $-0,9$ & $-1,4$ & $-1,1$ & 0 & $\mathbf{1 , 2}$ \\
\hline İșsizlik & 7,8 & 9,6 & 12,7 & 17,9 & 24,4 & 27,5 & 26,5 & 24,9 & 23,5 & $\mathbf{2 3 , 1}$ \\
\hline $\begin{array}{l}\text { Bütçe } \\
\text { Açı̆̆ı/GSYH }\end{array}$ & $-10,18$ & $-15,14$ & $-11,20$ & $-10,28$ & $-8,89$ & $-13,26$ & $-3,59$ & $-5,72$ & 0,45 & \\
\hline
\end{tabular}

Kaynak: OECD (2018), General government deficit (indicator). doi: 10.1787/77079edb-en ve http://www.imf.org/en/countries 05 Nisan 2018.

\section{Aşırı sağ $\breve{g}^{4}$}

Altın Şafak, Yunan aşırı sağının bir temsilcisi olarak Avrupa'da oylarını artıran aşırı sağ partilerden birisi olmuştur.1985 y1lında Nikolaos Michaloliakos liderliğinde örgütlenen Altı Şafak, 1993 yılında resmi parti olarak siyasi faaliyetlerine başlamıştır. Kuruluş yıllarında Makedonya sorunu üzerinden milliyetçi bir çizgi izleyen Parti, bu milliyetçi söylemlerine rağmen $\mathrm{AB}$ üyeliğinden ayrılma konusunda Avrupa'daki diğer aşırı sağ partilerden ayrılmakta ve bu durumun ülkeye zarar vereceği tezini savunmaktadır. Bu çerçevede, diğer aşırı sağ partilerin aksine $A B$ 'nin varlığından ziyade $\mathrm{AB}$ kurumlarına yapılan yetki devrine karşıdır. $\mathrm{AB}$ 'nin gevşek bir yapılanma ile devam edebileceğine inanan Michaloliakos, ABD'ye ise tamamen karşıdır. Bu noktada AB kurumları ile IMF ve Dünya Bankası tarafından dayatılan kemer sıkma politikalarını ise şiddetle eleştirmektedir (Güler, 2014).

Altın Şafak Partisi'nin son on yılda yapılan seçimlerdeki başarı oranlarına bakıldığında 2009 yılında yapılan genel seçimlerde \%0.3 olan oy oranını 2012 yılının Mayıs ayında yapılan seçimlerde \%6.97 oy alarak çok hızlı bir yükseliş göstermiştir. Bu oranla Altın Şafak, SYRIZA ve Yeni Demokrasi partilerinden sonra üçüncü sıraya yerleşerek PASOK gibi köklü partileri geride bırakmayı başarmıştır.

Tüm çabalara rağmen hükümetin kurulamaması sebebiyle Haziran ayında tekrarlanan seçimlerde Altın Şafak \%6.92 oyla mevcut oylarını korumuştur. Ekonomik krizin en şiddetli şekilde hissedildiği bu yıllarda bir sonraki Parlamento seçimi olan 2015 yılının Ocak ayında yapılan seçimlerde de \%6.28 oy alarak ülkedeki popülaritesini devam ettirmiştir. Aynı yılın Ağustos ayında

\footnotetext{
${ }^{4} \mathrm{Bu}$ çalışmada Yunanistan'daki aşırı sağ eğilimlerin temsilcisi olarak Altın Şafak Partisi’ne yer verilmiştir. 2016 yılında Kyriakos Velopoulos tarafından kurulan Helen Çözümü isimli aşırı sağ parti, çalışmanın inceleme aralığında (2008-2018) yapılan seçimlere katılmamış olduğundan inceleme dışında tutulmuştur.
} 
Başbakan Alexis Çipras'ın istifasıyla Eylül ayında seçimler yenilenmiş ve Michaloliakos, \% 6-7 bandını koruyarak \%6.99 oy almayı başarmıştır. Bu durum krizin etkilerinin en fazla hissedildiği ilk on yıllık dönemde Partinin belirli bir istikrarı koruduğunu göstermektedir (https://www.hellenicparliament.gr, 2019).

Tablo 6: Yunan Meclisi Altın Şafak Partisi Seçim Sonuçları (2008-2018)

\begin{tabular}{|l|c|c|}
\hline Seçim & Oy Oranı & $\begin{array}{c}\text { Sandalye } \\
\text { Sayısı }\end{array}$ \\
\hline $\mathbf{2 0 0 9}$ & $\mathbf{\% 0 . 3}$ & - \\
\hline $\mathbf{2 0 1 2}$ (Mayıs) & $\% 6.97$ & $21 / 300$ \\
\hline $\mathbf{2 0 1 2}$ (Haziran) & $\% 6.92$ & $18 / 300$ \\
\hline $\mathbf{2 0 1 5}$ (Ocak) & $\% 6.28$ & $17 / 300$ \\
\hline $\mathbf{2 0 1 5}$ (Eylül) & $\% 6.99$ & $18 / 300$ \\
\hline
\end{tabular}

Kaynak:https://www.hellenicparliament.gr/en/Vouli-ton-Ellinon/ToPolitevma/Ekloges/Eklogika-apotelesmata-New/\#Per-13

\section{Aşırı să̆-ekonomik kriz}

Yunanistan'da 2007-2015 arası dönemde yapılan seçimlerde Altın Şafak Partisi'nin oylarını iki kata çıkarttığı görülmektedir. Ekonomik kriz sebebiyle halkta oluşan kaygıların daha önce denenmemiş olan Altın Şafak Partisi'nin oylarını arttırdığı sonucunu doğurmuştur. Bu durum Yunanistan örneğinde ekonomik krizin aşırı sağın oylarını arttırdığı hipotezini doğrulamaktadır.

Yunanistan'da yaşanan borç krizinin en önemli etkileri, halkın gelir seviyesinin düşmesi, işsizliğin yüksek seviyelere ulaşması ve $\mathrm{AB}$ kurumları tarafından dayatılan kemer sıkma politikaları nedeniyle devletin sosyal harcamalarda kısıntıya gitmesidir. Yunan kamuoyunda bu sorunun faturas1 yolsuzlukla ve krizi yönetememekle suçlanan politikacılara kesilmiştir. Bu algı da daha önce denenmemiş bir siyasi parti olarak Altın Şafak için eşsiz bir firsat olmuştur.

Yunanistan'da ekonomik kriz aynı zamanda sosyal yönleri ile de değerlendirilebilir. İşsizlik özellikle genç nüfusu içerecek biçimde gelişmiş ve yaşam standardında kayıplar ortaya çıkmıştır. Bu durum yabancı düşmanlığına dayalı insani duyguların artmasına ve göçmenliğe karşı ülke çapında gösterilere neden olmuştur. Göçmenler bu ülkede hem işgücü anlamında bir rakip hem de kendi zihniyet ve kültürel öğelerine bir tehdit olarak algılanmışlardır (Dudin vd.,2016: 4).

\section{4.İtalya}

\section{Ekonomik kriz}

Aşağıdaki tabloya göre İtalya, 2008 y1lı itibariyle \%7 civarında olan işsizliğin 2017 itibariyle \%11,5'a ulaştığı bir süreç yaşamıştır. Büyüme oranları itibariyle bakıldığında 2009'daki negatif 5,5'lik büyüme dışında durağan bir eğilim gösterdiği gözlenmektedir. Küresel kriz İtalya ekonomisi üzerindeki ilk etkilerini enflasyon oranlarını yükselterek göstermiş, devamında ise pozitif fakat oranı düşük kalmıştır. Bu durum karşısında IMF İtalya ekonomisinin tekrar kriz öncesi seviyesine gelmesinin 2020'lerin ortalarında gerçekleşeceği beklentisini ortaya koymuştur (Çetin, 2017: 16).

İtalya, küresel ekonomik krize yüksek kamu borcu ile yakalanmış bir ülkedir. Bu borç ülkenin gayri safi yurtiçi hasılasının yüzde 138'ine tekabül etmektedir. Bu da, 60,8 milyon nüfuslu ülkenin her bireyinin 39 bin 485 Avro borcu olduğu anlamına gelmektedir. İtalya bu anlamda Avrupa'da çeşitli bankalarda bulunan tahvillerin önemli bölümünün sahibidir). Bu durum faiz oranlarının yükselmesine yol açarak büyüme beklentilerinin olumsuz etkilenmesine neden olmuştur. 
Yapısal problemler ve verimlilik kayıpları bu olumsuz algının derinleşmesine neden olmuştur (www.dunya.com,

İtalya ayrıca araştırma ve yenilik alanında da bazı zorluklarla karşı karşıyadır. İlk olarak, Yetersiz reformlar ve yükseköğretim sisteminin düşük performansı ve kalifiye insan oranı düşüktür. İkinci olarak yolsuzluklarla mücadelenin engellenememesi gelecekteki büyümeyi olumsuz etkilemektedir (Boschele, 2015: 149).

İtalya'da işsizlik oranının 2012 yılı sonunda yüzde 11 civarında gerçekleşmiş olması işsizlikle mücadelede alınan önlemlerin yetersizliğini göstermektedir. Bu oran, İtalya için son on iki y1lın en yüksek işsizlik oranıdır. Daha sonraki yıllarda da bu oran düşürülememiştir. İtalya'da ekonomik krizin işsizlik üzerinde yaptığı etkinin derinleşmesiyle, Ekim 2008'de alınan ve Ocak 2009 'da (Kanun 2/2009) yapılan düzenleme ile işsizlik yardımından yararlanmaya yönelik başvuru hakkındaki kısıtlamalar azaltılmıştır(Gençler, 2016).

Tablo 7: Küresel Kriz Sonrası İtalya'da Makro Ekonomik Göstergeler

\begin{tabular}{|l|l|l|l|l|l|l|l|l|l|l|}
\hline & 2008 & 2009 & 2010 & 2011 & 2012 & 2013 & 2014 & 2015 & 2016 & 2017 \\
\hline Büyüme Hızı & $-1,1$ & $-5,5$ & 1,7 & 0,6 & $-2,8$ & $-1,7$ & 0,1 & 0,8 & 0,9 & 1,5 \\
\hline $\begin{array}{l}\text { Enflasyon } \\
\text { (Tüfe) }\end{array}$ & 3,5 & 0,8 & 1,6 & 2,9 & 3,3 & 1,2 & 0,2 & 0,1 & $-0,1$ & 1,4 \\
\hline İşsizlik & 6,7 & 7,7 & 8,4 & 8,4 & 10,7 & 12,1 & 12,7 & 11,9 & 11,7 & 11,6 \\
\hline $\begin{array}{l}\text { Bütçe } \\
\text { Açı̆̆g/GSYH }\end{array}$ & $-2,69$ & $-5,27$ & $-4,25$ & $-3,71$ & $-2,93$ & $-2,95$ & $-3,03$ & $-2,58$ & $-2,49$ & \\
\hline
\end{tabular}

Kaynak: OECD (2018), General government deficit (indicator). doi: 10.1787/77079edb-en ve http://www.imf.org/en/countries 05 Nisan 2018.

\section{Aşırı să}

İtalya aşırı sağını temsil eden resmi adıyla Kuzey Ligi (resmi olmayan değişiklikle adı Lig olarak değiştirildi) Partisi (LN) 1991 yılında Umberto Bossi tarafından kurulmuştur. LN, İtalya'nın federal bir devlet, mali federalizm, bölgeselcilik ve özellikle kuzey bölgeler için daha büyük bölgesel özerkliğe dönüşümünü savunmaktadır. Parti başlangıçta Padania Milliyetçiliği olarak adlandırılabilecek şekilde Kuzey'in ayrılığını başlıca politik hedefleri arasında göstermektedir.

$\mathrm{Bu}$ çalışmanın zaman aralığına giren dönemde yapılan seçimlere bakıldığında kurucu lideri Bossi yönetiminde Parti, 2008 yılında yapılan Temsilciler Meclisi seçimlerinde \%8.3, Senato seçimlerinde ise \%7.9 oy almıştır. Bossi' den sonra partinin başına gelen Robert Maroni döneminde yapılan 2013 seçimlerinde ise oylarda yarıya yakın bir düşüş olarak sırasıyla Temsilciler Meclisi'nde \%4.1, Senato'da ise \%4.3 oy almıştır. Mevcut parti başkanı olan Matteo Salvini ise 2018 seçimleri öncesinde Partinin ismini fiilen değiştirerek sadece Lig adıyla seçim propagandasını yapmış ve "öteki" olarak göçmenleri tanımlamıştır. İzlediği bu siyaset İtalyan halkında karşı1lık bulmuş ve Temsilciler Meclisi'nde \%17.4, Senato'da ise \%17.6 oy alarak selefi Maroni'ye göre partisinin oylarını dört kattan fazla arttırmıștır (www.parties-and-elections.eu, 2019). Bu sonuçlar Lig Partisi'ne Beş yıldız Hareketi ile koalisyon yapma şansı verecek ve böylelikle Batı Avrupa'nın ilk Euroskeptik iktidarı kurulmuş olacaktır.

Parti, 1989'dan beri federalizmi savunan siyasetinin yerine artık İtalyan milliyetçiliğine vurgu yapan bir tutum koymakta ve AB'nin ulus-üstü yapısını eleştirmektedir. Bu eleştiri iktidar ortağı olan Beş Yıldız'ın da siyasalarıyla örtüşmektedir. Yeni hükümetin ilk amaçlarında biri, geliri olmayanlara yoksulluk yardımı olmuştur. Bununla birlikte daha fazla kamu harcaması ile iç talebi 
canlandırmayı amaçlamakta ve kemer sıkma politikalarına karşı çıkmaktadır. Bunun yanı sıra Avro kullanmaktan kaynaklana $\mathrm{AB}$ ekonomik denetiminin ve $\mathrm{AB}$ antlaşmalarının gözden geçirileceği sözünü veren koalisyon ortakları ülke içinde "yasa dışı göçmenlerin" ülkelerine derhal geri gönderileceği ve izinsiz Çingene yerleşimlerinin kaldırılacağı taahhüdünde bulunmuştur (Bilgen,2018).

Tablo 8: İtalya Temsilciler Meclisi Lig Partisi Seçim Sonuçları(208-2018)

\begin{tabular}{|l|l|l|}
\hline Seçim & Oy Oranı & Sandalye \\
\hline $\mathbf{2 0 0 8}$ & $\% 8.3$ & $60 / 617$ \\
\hline $\mathbf{2 0 1 3}$ & $\% 4.1$ & $18 / 617$ \\
\hline $\mathbf{2 0 1 8}$ & $\% 17.4$ & $73 / 617$ \\
\hline
\end{tabular}

Kaynak: http://electionresources.org/it/

\section{Aşırı săg-ekonomik kriz}

İtalya'da 2008 seçimlerinde \%8 civarında olan aşırı sağ oylarda 2013 yılında yarı yarıya bir düşüş görülmüştür. Burada işsizlik oranları ile aşırı sağın oyları arasında ters bir orantı olduğunu göstermektedir. 2018'de yapılan seçimlerde ise Kuzey Ligi yaklaşı \% 13 oy almış ve sağ ittifakla birlikte seçimi kazanmıştır.

Bu durum İtalya' da da ekonomik kriz dışında başka faktörlerin (mülteci krizi gibi) aşırı sağın artışında etkili olduğunu göstermektedir. Zira İtalya, denize kıyısı olan bir ülke olarak deniz yoluyla Avrupa'ya gelmeye çalışan yasadışı göçmenlerden en fazla etkilenen ülkelerden biridir. Hatta bu çerçevede de sırasıyla Mare Nostrum ve Triton gibi arama kurtarma operasyonları ile bu soruna çözüm bulmaya çalışmıştır. Bu nedenle ekonomik krizi takip eden on yıllık sürecin ikinci beş y1llık periyodunda aşırı sağın yükselişindeki başlıca faktör olarak mülteci meselesinin düşünülmesini gerekli kılmaktadır. İtalya aşırı sağını temsil eden Lig Partisi'nin 2018 yılında isminin başındaki "Kuzey" ifadesini atarak söylemini de Güney İtalyalılardan göçmenlere çevirmesi de bu durumu kanitlar niteliktedir.

\section{Sonuç}

2008 yılında ABD'de başlayarak Avrupa ülkelerine yayılan ve Avro bölgesindeki mali sorunlarında etkisiyle pek çok ülkeyi etkisi altına alan ekonomik kriz, ekonomik etkilerinin yanında politik ve toplumsal sonuçlar da doğurmuştur. AB'de 2008 yılında başlayan ekonomik kriz, Avrupa ülkelerinde aşırı sağın yükselmesinin nedeninden ziyade tetikleyicisi olmuştur. Ekonomik kriz öncesi toplumda biriken gerilim, kriz sebebiyle açığa çıkmış ve üye devletlerin sosyal harcamaları kısmasıyla toplumsal rahatsızlık artmıştır. AB'nin kuruluşundan beri çözmeye çalıştı̆̆ 1 sorunların başında gelen "Avrupalılık" bilincinin yerleştirilememesi ve bu nedenle toplum nezdinde ulusal kimliklerin ön planda olma durumunu koruması, AB'nin sosyal, ekonomik ve siyasi bütünleşmesi önünde önemli bir engel olarak kalmış ve ekonomik krizin etkilerinin daha ileri bir düzeye taşınmasına neden olmuştur. Ekonomik krizden kaynaklanan olumsuz etkilerin faturasının AB'ye bir yük olduğu düşünülen göçmenlere çıkarılması milliyetçilik duygularını körüklemiş ve bu argümanları vaatlerinin başına yerleştiren aşırı sağ partileri güçlendirmiştir.

Ekonomik kriz her ne kadar Avrupa'da ekonomik sorunların ötesine geçmiş ve sosyal ve siyasal yapıları büyük ölçüde etkilemişse de Avrupa'da siyasal tercihlerin bu denli radikal bir şekilde değişime uğramasının temelinde sadece ekonomik krizin bulunduğunu söylemek, kendisine tarihsel bağlamda her zaman bir öteki yaratan Avrupa için doğru olmayacaktır. En azından 2008 krizi için ekonominin aşırı sağı açıklamadan yegane argüman olduğu fikri pek çok yanlışlanabilir iddiaları önümüze getirebilir. Bunun yanında ekonomik kriz yaşanan ülkelerde içe kapanma, milliyetçi unsurların artışı gibi eğilimler ön plana çıkmaktadır. Ulusal referanslara dayanan söylemler ve 
politikalar, kriz ortamındaki halk için aranılan umut olmaktadır. Bir anlamda krizin acısını ötekinden çıarmak üzere var olan yabancı düşmanı ve ırkçı düşünce ve duyguların harekete geçtiği belirtilebilir. Bu çerçevede ekonomik krizlerin Avrupa'nın öteki tanımına katkıda bulunduğu ve fakat doğrudan ötekini var eden bir faktör olmadığı ifade edilebilir.

$\mathrm{Bu}$ çalışmada incelenen ülkelerde görülmektedir ki ekonomik kriz her ülkede aşırı sağı arttırmamıştır. $\mathrm{Bu}$ durumda aşırı sağın artışında ekonomik krizden başkaca faktörlere (göçmen sayıları, azınlık nüfusun oranı gibi) bakılması gerekmektedir.

Ekonomik krizler aşırı sağın oylarının artışına doğrudan etkide bulunmasa bile onları «besleyen» bir faktördür. Zira bu durum bazı ülkelerde dolaylı yoldan bir etkiye sebep olmuştur. Ekonomik krizden ülkesi etkilenmese bile krize giren ülkelere yaptığı finansal yardımları eleştiren gelişmiş ülke vatandaşları da sandıkta aşırı sağ partilere oylarını vererek bu yardıma olan tepkilerini göstermiş̧lerdir.

Bazı ülkelerde ise ekonomik krizin etkisi çok şiddetli olmakla birlikte aşırı sağ partiler incelenen dönemde bir yükselme eğilimine girmemiştir. Bu duruma sebep olarak da bu ülkelerdeki sosyal ve politik ayrışma ve ulus bilincinin oluşmamış olması gösterilebilir. (İspanya ve Belçika gibi)

Ekonomik krizden en çok etkilendiği bilinen İtalya ve Yunanistan aynı zamanda Avrupa’ya deniz yolundan ulaşım güzergahında olmaları sebebiyle göçmen krizinden de en çok etkilenen ülkelerin başında gelmektedirler. Özellikle AB'nin Türkiye ile yaptığı 18 Mart Mutabakatına kadar bu iki ülke deniz yolundan Avrupa'ya ulaşmaya çalışan ve bu uğurda pek çoğu boğularak hayatını kaybeden göçmenlerin ilk varış noktalarıydı. Bu durum da bu iki ülkedeki aşırı sağ oyların artışına en büyük etmenlerden biridir. Ancak özellikle İtalya'nın AB ile ekonomik krizin çözüm yollarından biri olarak oluşturulan Bütçe Anlaşması kurallarından dolayı yaşadığı krizler ve bu ülkede krizin hala tam olarak bitirilememiş olması aşırı sağın popülaritesini devam ettirmektedir.

$\mathrm{Bu}$ çalışma tam da bu nedenle literatürdeki «ekonomik krizler aşırılıkları besler» hipotezini test etmek için yapılmış ve görülmüştür ki ekonomik kriz, aşırı sağın yükseliş nedenleri sıralandığında ilk sırada gelecek olan bir etmendir. Ancak ardından gelen konjonktürel gelişmeler de (mülteci krizi, Trump'ın ABD başkanı seçilmesi, Brexit gibi) aşırı sağı beslemiştir. Bu gelişmelerin uzun dönemli etkileri devam ettiği sürece pek çok ülkenin siyasi yelpazesinin yeniden şekilleneceği düşünülmektedir.

\section{Kaynakça}

AB Genel Sekreterliği (2011), küresel krizin AB üyesi ülke ekonomilerine etkileri ve gelecek döneme ilişkin beklentiler, Ankara

Aktan, Ç. ve Şen, H. (2001). "Ekonomik kriz: nedenleri ve çözüm önerileri”. Yeni Türkiye, Ekonomik Kriz Özel Saylsl. 42(2): 1225-1230. https://doi.org/10.30976/susead.302205

Avrupa Birliği Bakanlığı (2012). Avro bölgesinde işsizlik. Ankara

Backes, U. ve Mudde, C.(2000). "Germany: extremism without successful parties", Parliamentary Affairs, 53(3):457-468. https://doi.org/10.1093/pa/53.3.457

Balc1, A. ve Cicioglu, F. (2019), "Turkey in the discourse of European far right: the uses and abuses of Turkey's membership process for a counter-hegemony, Journal of Contemporary European Studies", https://doi.org/10.1080/14782804.2019.1677574

Başoğlu, U. ve Ceylan, A.(2001), Finans teori kurum uygulama. Bursa: Ekin Kitabevi. 


Bilgen, E. (2018)“İtalya’nın $\quad$ Değişim Hükümeti”,
https://www.birikimdergisi.com/haftalik/8942/italya-nin-degisim hukumeti\#.XepECJMzbDc (Erişim Tarihi 06.12.2019).

Boschele, M.(2015) "Italy and the economic crisis: political change and crisis of legitimacy", Academic Journal of Interdisciplinary Studies 4(31):147-151. https://doi.org/10.5901/ajis.2015.v4n3s1p147

Çetin, S.E. (2017). "Değişim Sürecindeki AB Ekonomisi”, SETA Analiz:220.

Dağdelen, İ. (2011). "Avrupa bütünleşme sürecinde Yunanistan borç krizi”, Ankara Avrupa Çalışmaları Dergisi,10(2):1-26. https://doi.org/10.1501/avraras_0000000163

Dudin, M.N. vd (2016) "Financial crisis in Greece: challenges and threats for the global economy" International Journal of Economics and Financial Issues 6(5):1-6.

Dursunoğlu, A. (2009). Teori ve İlişkileri ile global ekonomik kriz. Bursa: Çizgi Kitabevi.

Durusoy, S. Ve Şamiloğlu, Ö.(2012). “AB’nin zayıf ekonomik halkası Yunanistan'ın ekonomik krizi dinecek mi?" Alternatif Politika,4(1):84-128.

Eğilmez, M. (2009). Küresel finans krizi, İstanbul: Remzi Kitabevi.

Eraslan C. ve Timurtaş, M.E. (2015). "Avrupa borç krizinin seçilmiş ülke örnekleri üzerindeki etkileri”, Gazi Iktisat ve Işletme Dergisi,1(2):17-54. https://doi.org/10.3848/iif.1999.161.2332

Funke vd.(2016). "Going to extremes: Politics after financial crises, 1870-2014", European Economic Review", 88 :227-260. https://doi.org/10.1016/j.euroecorev.2016.03.006

Gençler, A.(2011). “Avrupa Birliği’nde krizin işsizliğe etkisi ve istihdam teşvikleri.” Çalışma Illişkileri Dergisi, 2(1): 1-25

Güler, S. (2014). “Avrupa'da aşırı sağın yükselişi: Yunanistan'da Altın Şafak Partisi örneği”, Bilgesam, http://www.bilgesam.org/incele/285/-avrupa\%E2\%80\%99da-asiri-saginyukselisi--yunanistan'da-altin-safak-partisi-ornegi/\#.WsI2jy5uY_4, (Erişim Tarihi 06.12.2019). https://doi.org/10.32450/aacd.676473

Hondur, M.(2012). "Maliye politikaları ve bütçe uygulamaları", SDE Analiz.

http://www.electionresources.org/at/ (Erişim Tarihi 06.12.2019)

http://www.electionresources.org/de/ (Erişim tarihi 06.12.2019)

https://www.dunya.com/finans/haberler/kuresel-ekonominin-yeni-bas-agrisi-italya-haberi-417746. (Erişim tarihi 07.12.2019).

https://www.hellenicparliament.gr/en/Vouli-ton-Ellinon/To-Politevma/Ekloges/Eklogikaapotelesmata-New/ (Erişim tarihi 06.12.2019).

İltaş, T. (2019). "Ekonomik krizlerin politik sonuçları: aşırı sağın yükselişi”, Yayınlanmamış Yüksek Lisans Tezi: Marmara Üniversitesi Avrupa Araştırmaları Enstitüsü, İstanbul.

Kallis A.(2015). “Avrupa'da aşırı sağın yükselişi”, SETA Analiz:119

Kibritçioğlu, A.(2015). “2008 Küresel finans krizi öncesi krizler ve Türkiye ekonomisi.” İktisadi Krizler ve Türkiye Ekonomisi. (Der.) N. Eroğlu vd. Ankara: Orion Kitabevi.503-518. https://doi.org/10.3848/iif.2003.202.4784 
Kriesi, H.(2012). "The political consequences of the financial and economic crisis in Europe: electoral punishment and popular protest", Swiss Political Science Review 18(4): 518-522. https://doi.org/10.1111/spsr.12006

Mudde, C. (2014). The far right and the European elections. Current History, March: 98-103.

Öniş, Z. Ve Kutlay, M.(2012). "Ekonomik Bütünleşme/ Siyasal Parçalanmışlık Paradoksu: Euro Krizi ve Avrupa Birliği'nin Geleceği”, Uluslararası İlişkiler 9(33): 3-22

"Parties and Elections in Europe", http://www.parties-and-elections.eu/italy.html (Erişim tarihi 06.12.2019).

Songülen İnanç, Z. ve Çetin, S.(2011). “Avrupa'nın kendine dönen silahı: dışlayıcılık ve ayrımcılık”, SDE Analiz,

Stockemer, D.(2017). "The economic crisis (2009-2013) and electoral support for the radical right in Western Europe-some new and unexpected findings", Social Science Quartely 98(5):1536-1553. https://doi.org/10.1111/ssqu.12374

Tandoğan, Ş.M. (2019). “Avrupa'da aşırı sağın yükselişi: Almanya ve Fransa örnekleri”, Sakarya Üniversitesi Sosyal Bilimler Enstitüsü Yayınlanmamış Yüksek Lisans Tezi

Ultan, M. Ö. (2016). AB'de Yasa dışı Göçün Önlenmesi ve ülke uygulamaları, İstanbul: Nobel Yayınları

Uzunçayır C. (2017). "Batı Avrupa'da aşırı sağ partiler neden yükseliyor?”, Türk\&İslam Dünyası Sosyal Araştırmalar Dergisi 4(5):364-401. https://doi.org/10.16989/tidsad.1423

Vittori D.(2016). "Book review." Acta Politica (51):400-402.

Yılmaz, B. E. (2013a). Küresel krizin Avrupa'da borç çıkmazına dönüşümü. İstanbul: Derin Yayınlar1. https://doi.org/10.1501/avraras_0000000026

Yılmaz, B.E. (2013b) "Küresel krizin PIIGS (Portekiz, İrlanda, İtalya, Yunanistan ve İspanya) ülkeleri ile Türkiye'nin makroekonomik değişkenlerine yansımaları, Ankara: Ankara Sanayi Odas1 Yayını, Kasım-Aralık. 